\title{
THE USE OF DRILL TECHNIQUES IN TEACHING PRESENT AND PAST TENSE PRIVATE GRAMMAR TOWARD STUDENTS IN ENGLISH STUDY PROGRAM OF UNIMA
}

\author{
Fivy Andries
}

\begin{abstract}
This study intends to describe the used of drill techniques can improve understanding and the ability of students to use Simple present and past tense. This research can be classified into quasi-experimental research using the pre-test and post-test design. The research was conducted at the beginning of semester in 2018/2019 academic in year in the first semester, class A amounted to 45 students as the experimental class and class B which amounted to 45 students as a control class. The data were collected through a test. The result showed that the use of drill techniques has been able improve student competence and English performance. The average score of the post test (74) is higher than the pre-test(51.92), and the percentage of student whose grades are $71-100$ is $100 \%$ while in the pre-test only $18,51 \%$. The researcher came to the conclusion that it was proven, drill techniques can be used as a technique in teaching English to improve the competence and performance of English language students.
\end{abstract}

\section{Keywords: Drill technique, simple present, simple past}

\section{Introduction}

Brown (2000: 60) states that understanding language theories is one of the important aspects that must be possessed by a language teacher because his understanding will determine what he will teach. Furthermore, according to Brown, language has a systematic understanding, a collection of arbitrary symbols that can be both vocal and visual, as a medium of communication, and applied in a speech or cultural context. Meanwhile Halliday argued that language as a tool for expressing functional meaning and meaning was realized through the structure of grammar and vocabulary. According to the functional view, language relates to social behavior and represents the desires / intentions of the wearer (Hutchinson and Waters, 1987: 31

Teaching grammar / structure is one of the main subjects in the Department of English Language Education is one of the competencies that always gets the main attention in teaching English, both in secondary schools and universities compared to other fields of expertise, such as speaking, listening, writing, and reading. However, in reality learning this subject has quite serious problems. This can be seen from the low specific structure values in the Simple Present and Past Tense Tenses. This situation affects other subjects, namely writing speaking and reading. Lecturers experienced many obstacles when teaching this course. In addition, the average thesis supervisor must work extra to correct the final grammar of the student. One of the problems is caused by the teaching / learning model used. So far there has been a tendency that the instructor tends to give priority to providing theoretical explanations and then asks students to make loose sentences. Students tend to only take existing examples so that often they cannot apply their knowledge in an appropriate and appropriate context. Even more concerning, students often make fundamental mistakes when preparing a thesis.

Furthermore, to overcome this problem, the writer views the need to carry out teaching structure with engineering drill. In this case, researchers want to know the extent to which the effectiveness of using drill techniques in an effort to motivate students to improve their grammar abilities. 


\section{Formulation Of The Problem}

How far this techniques can affect the ability of students of the English Language and Literature Program in understanding and using Simple Present and Past Tense in sentences.

\section{Research Purposes}

This study aims to see whether the use of drill techniques can improve understanding and the ability of students to use Simple Present and Past Tense.

\section{Teaching and Learning Process}

The teaching and learning process is at the core of the overall education process with the teacher as the main role holder. The teaching and learning events are rooted in many views and concepts. Therefore the embodiment of the teaching and learning process can occur in various models. Bruce Joyce and Marshal Weil suggested 22 teaching models grouped into 4 ha, namely: Information processes, personal development, social inter action and behavior modification (Joyce \& Weil, Models of Teaching, 1980)

Learning strategies are ways that will be selected and used by a teacher to deliver learning material so that it will be easier for students to receive and understand learning materials that ultimately can be mastered learning objectives at the end of learning activities. Learning strategies must contain an explanation of the methods / procedures and techniques used during the learning process takes place (Hamzah, 2009: 2).

\section{Drill Technique}

Definition of Drill Technique

The method of teaching is the way the teacher gives lessons and how students receive lessons at the time the lesson takes place, whether in the form of telling or raising. The teaching method is a tool to create a conducive teaching and learning process. With this method it is expected to grow a variety of student learning activities in connection with teaching teachers, in other words creating educational interactions between teachers and students. In this interaction the teacher acts as a driver or mentor, while students act as recipients or guided. This interaction process will run well if students are more active than the teacher. Therefore a good teaching method is a method that can foster student learning activities and in accordance with the conditions of learning. And each teacher must understand the position of the method as one component that affects the teaching and learning process.

In Nana Sudjana's book, the drill method is an activity to do the same thing, repeatedly in earnest with the aim of strengthening an association or perfecting a skill to become permanent. Drill is a teaching model where each student or student carries out training activities to become more agile and skilled. So this method is an activity in the form of repeated repetitions of the same thing.

\section{Types of Drill Methods} follows:

The forms of the Drill Method can be realized in various forms of techniques, namely as

a. Inquiry Technique (group work)

This technique is done by teaching a group of students to work together and solve problems by working on the tasks given.

b. Discovery Technique (discovery)

Done by involving students in the process of mental activities through exchange of opinions, discussions.

c. Micro Teaching Technique

Used to prepare students as prospective teachers to face teaching work in front of the 
class by gaining added value or knowledge, skills and attitudes as a teacher.

d. Learning Module Techniques

Used by teaching students through learning packages based on performance (competence).

e. Independent Learning Techniques

Done by telling students to study on their own, both in class and outside the classroom.

The Purpose of Using the Drill Method

The Drill method is usually used for the purpose that students:

- Having motor skills / movements, such as memorizing words, writing, using tools.

- Develop intellectual skills, such as multiplying, dividing, summing.

- Having the ability to connect between things with others.

\section{Requirements in the Drill Method}

- The training period must be interesting and fun.

- For satisfactory training results, intrinsic interest is needed.

- Each step of progress achieved must be clear.

- The results of the best exercises that use little emotion

- Exercises are only for automatic action skills.

- Exercise is given by taking into account the ability / endurance of students, both mental and physical.

- There is mobilization and correction from the teacher who is training so that students do not need to repeat a wrong response.

- Exercises are given systematically.

- Exercise is better given to individuals because it facilitates direction and correction

- Exercises must be given separately according to the field of knowledge.

\section{Principles and Guidelines for Using the Drill Method}

- Students must be given a deep understanding before certain exercises are held.

- Exercise for the first time should be diagnostic:

- At the beginning, do not expect perfect reproduction.

- In retesting, the difficulties arising must be examined.

- Correct response must be strengthened.

- Only then will variations, development of meaning and control be held

- The training period is relatively short, but it must be done frequently.

- At the time of training essential processes must be carried out.

- In practice the first is accuracy, speed and in the end both must be achieved as a unit.

- Exercise must have meaning in a wider range of behaviors.

- Before carrying out, students need to know in advance the meaning of the exercise.

- He needs to realize that the exercises are useful for later life.

- He needs to have the attitude that the exercises are needed to complete learning.

\section{Advantages or Goodness of the Drill Method}

- The material of learning given in an atmosphere that will truly be more firmly embedded in the pupil's memory, because all thoughts, feelings, wills are concentrated on the lessons being trained.

- Students will be able to use their mind power better, because with good teaching, students will become more organized, careful and encourage their memory. 
- The presence of supervision, guidance and correction immediately and directly from the teacher, allows students to make corrections at that time. This can save learning time as well as the students immediately know their achievements.

\section{Grammar}

As we know, that for proper and correct English, you must master the Grammar or English grammar in advance. English is very influenced by circumstances and governed by grammar. Brown (1993: 347) says: amm Grammar is a governing system of rules the conventional arrangement and relationship of words in a sentence. So grammar discusses how to make sentences and gives instructions to string words into good sentences so that they can be understood and used to communicate easily and precisely. That's why we must understand grammar.

\section{Tenses}

To convey a purpose, wishes, statements, news, events, other actions, in writing or verbally so that they can be understood and understood clearly and correctly. When an event occurs, in English we must use the right and correct form of time (tense). Tense is a form of verb in English to indicate the time (present, future, or past) of an action or event (Purnama: 2012). So Tenses are generally used to form a sentence in English based on the time of the event or event. ... An event or event can take place in the past or the Past, now or the Present and in the future or the Future.

\section{Use of Simple Present Tense}

Simple Present tense is tenses that are used when an event is taking place at this time or an event that takes place repeatedly (habits). These tenses are the most commonly used tenses in English.

\section{Simple Present Tense Formula}

To form simple Present tense sentences, usually used basic form verbs, or Verb 1. Except for third person pronouns, use Verb $1+\mathrm{s} / \mathrm{es}$. As shown in the table below.

\begin{tabular}{|c|c|c|}
\hline Subject & Verb & The Rest of the sentence \\
\hline $\begin{array}{c}\text { I / You / They / } \\
\text { We }\end{array}$ & Go & to the school by bus \\
\hline She / He / It & goes & to the school by bus \\
\hline
\end{tabular}

The verb spelling form in the third person (She, He, It), depends on the end of the verb (verb).

1. For verbs ending in - $\mathrm{O},-\mathrm{CH},-\mathrm{SH},-\mathrm{X}$, or $-\mathrm{Z}$, add -ES.

- go - goes

- catch - catches

- wash - washes

2. For verbs (Verb) ending in consonant $+\mathrm{Y}$, remove $\mathrm{Y}$, and add -IES.

- carry-carries

- $\quad$ study - studies

Whereas, for verbs ending in $+Y$ vowels, just add $-S$.

- play-plays

- $\quad$ say - says

- enjoy - enjoy 
The following is an example of a simple Present tense sentence that you can use.

1. Simple present tense to show recurring events that are taking place at this time.

- I take the motorcycle to the office

- The train to Bekasi leaves every hour.

- George sleeps seven hours every night during the week.

2. Simple present tense to show a fact.

- The President of Indonesia is Joko Widodo.

- A snake has no legs.

- Indonesia has 34 provinces, from Sabang to Merauke.

3. Simple Present tense to show a habit.

- Doni gets up early at 5 o'clock every day.

- John takes a bath twice a day.

- Every year at Lebaran day, most of people travel to their hometown.

Types of Simple Present Tense Sentences

Simple Present Tense Affirmative

To form simple Present tense Affirmative sentences, the formula is

$$
\mathrm{S}+\operatorname{Verb}(1) / \text { Verb dasar / to be (is, am, are) + O }
$$

Contoh simple Present tense Affirmative :

- Susi Pudjiastuti is the Ministry of Maritime Affairs and Fisheries.

- She reads Harry Potter book everyday.

- They watch new movies every sunday.

\section{Simple Present Tense Negative}

To form simple sentences Present tense is negative, usually using extras don't know not before the verb, EXCEPT To Be and Capital, the formula is $\mathrm{S}+$ Don '/ Doesn't + Verb (1) + O

If the verb / verb is To Be, then the formula becomes

$\mathrm{S}+($ is, am, are $)+$ not $+\mathrm{O}$

Example of simple present tense negative:

- Susi Pudjiastuti is not the Ministry of Maritime Affairs and Fisheries.

- She doesn't read Harry Potter book everyday.

- They don't watch new movies every sunday.

Note, for the third form subject (she, he it), after the word or not, the verb form is NOT ADDED $\mathrm{S} / \mathrm{ES}$

- Simple Present Tense Interrogative

- To form simple Present tense Interrogative sentences / question sentences, usually using an additional do or does in front of the sentence. The formula is as follows

- Do / Does $+\mathrm{S}+$ Verb $1+\mathrm{O}$

- The word do is used if the subject is I, you, they, or we. However, the word does is used if the subject is in the form of a third person (She, He, It).

- Example of interogative simple present tense:

\section{Does she read Harry potter book?}

Do they watch new movie everyday? 
Do you play basketball every morning?

If the verb (verb) is To Be or Capital, then do not use the word do or does. Example :

Is Susi Pudjiastuti the Ministry of Maritime Affairs and Fisheries?

Are you new staff of Wall Street English?

Are they football fans of Persija Jakarta?

\section{USE OF SIMPLE PAST TENSE}

Past Tense Is a Simple Form Of Verb That Functions To Explain An Event In The Past. Words That Are Often Used In This Type Of Tenses Are Yesterday, Last Two Days, Last Year And Others).

The Formulas Used For These Tenses Are:

- Positive Sentences: Subject + Verb2 (Past Tense) Subject + Be (Was / Were)

- Negative Sentence: Subject + Did + Not + Bare Infinitive

: Subject + Be (Was / Were $)+$ Not

- Question Sentence: Did + Subject + Bare Infinitive Be (Was / Were) + Subject

- Consider The Example Sentence That Uses The Following Past Tense:

(+) You Called Ryan.

(-) Did You Call Ryan?

(?) You Did Not Call Ryan.

In Its Use, Simple Past Tense Has Several Functions. The First Function Is To Explain Events In The Past And Have Been Completed At The Specified Time. Example:

- I saw a movie yesterday.

- I didn't see a play yesterday.

- Last year, I traveled to Japan.

Then, past tense is also used to explain some of the events that have been done in the past. Usually these events are carried out sequentially. Consider the following example:

- Mr. John finished work, walking to the beach, and found a nice place to swim.

- Jane arrived from the airport at 8:00, checked into the hotel at 9:00, and met the others at 10:00.

\section{Research Methods}

Research design

The design of this research is basically the whole process of thinking and mature determination of the things that will be done. He is the foundation of grounding, and can also be used as a basis for judgments by both the researcher himself and others on the assessment activities (Margono, 2009: 100). This research can be classified into quasi-experimental research using the pre-test and post-test design. According to Campbell and Stanley (2007: 84) quasi-experimental is often seen as an unrealistic experiment, because this type of experiment has not fulfilled requirements such as experimental methods that can be said to scientifically follow certain rules. The following is an experimental design according to Arikunto (2007: 79). Design of Experimental Research

$\begin{array}{lccc}\text { Group. } & \text { Pre- Test. } & \text { Treatment. } & \text { Post-Test } \\ \text { E. } & \text { O1. } & \text { X. } & \text { O2 } \\ \text { K. } & \text { O1. } & - & \text { O2 }\end{array}$

Keterangan:

E : Experiment group 
$\mathrm{K}$ : Control group

$\mathrm{X}$ : Treatment

O1 : Pre-Test

$\mathrm{O} 2$ : Post-Test

\section{Research Place}

This research will be conducted in the English Language Education Department, FBS Unima because drill techniques are rarely applied in Grammar learning processes and it is expected that drill techniques can improve grammar understanding Simple Present and Past Tense 1st semester students in English Language and Literature Study Program FBS Unima.

\section{Research Time}

This research was conducted at the beginning of semester in 2018/2019 academic year in the first semester of English Language and Literature Study Program, FBS, Unima. The time needed to carry out data collection in this study is 2 months, namely from April to June 2019.

\section{Population and Study Samples Population}

The population in this study is all first semester students of English language and literature study program, FBS, Unima 2018/2019 academic year, amounting to 90 students.

\section{Sample}

Samples are partially or representative of the population being studied (Arikunto, 2007: 131). The sample in this study was taken by simple random sampling technique. In this study there were 2 classes consisting of classes A and B and became the object of research. The researcher wrote the names of each class in pieces of paper, then rolled the paper and scrambled it. After that the researcher witnessed the guiding teacher to draw and determine the paper roll that came out first into the experimental class and the paper roll which came out second became the control class. The lottery results, selected class A, amounted to 45 students as the experimental class and class B which amounted to 45 students as a control class.

\section{Method of collecting data}

The test used in this study is a test of Grammar understanding skills Simple Present and Past Tense which aims to measure the level of student mastery in the structure of English.

\section{Research Instruments}

Determination of Research Instruments

The form of the instrument in this study was a test of grammar comprehension ability / simple present and past tense structure. The test in this study was made by the researchers themselves based on the English curriculum adjusted to the Green book reference.

\section{Results And Discussion}

The results of data analysis indicate that the use of drill techniques has been able to improve student competence and English performance. Before applying drill techniques in teaching Tobe simple present and past tense the post-test average score is only 51.92. However, when drill techniques are used to learn and memorize Tobe in the form of simple present and past tense as a treatment, the Average Score increases to 74. Increased Average Score means an increase in student achievement in learning. It was found that there were 6 students who got 100 in the post-test, 6 students got 99, 1 student got 97, 4 students got 96, 2 students got 95, 4 students got 92, 1 student got 84,2 students got grades, got 75,1 student gets 71 . Total students 
whose grades are $71-100$ are 27 . This means that $100 \%$ of students get good grades in the posttest. Compared with student achievement in the pre-test, no student gets 100, only 1 student gets 93, 1 student gets 81, 1 student gets 79, 2 students get 72, and the rest scores 68-20. In this case, the percentage of students with good grades is only $18.51 \%$.

Based on the results of the data analysis above, as the findings of this study, it can be concluded that the hypothesis is accepted because $100 \%$ of students get good grades in carrying out post-tests. More than $80 \%$ are expected before conducting this research. This proves that the use of technical drill with Tobe in simple present and past tense has succeeded in contributing not only to improving student competency and English performance but also has made the classroom atmosphere so lively and students enjoy learning English with engineering drill. Learning English by singing is fun.

Based on the discussion in the previous chapter, that the Average Score of the post-test (74) is higher than the pre-test (51.92), and the percentage of students whose grades are 71-100 is $100 \%$, while in the pre-test only $18,51 \%$, researchers came to the conclusion that it was proven, drill techniques can be used as a technique in teaching English to improve the competence and performance of English language students.

\section{Conclusion}

The use of drill techniques in the teaching of Grammar Present and Past Tense is successful, not only in improving student competency and English performance but also has encouraged students to enjoy learning English by practicing and have made students enjoy learning their English grammar without being bored, and maintaining what what they learn in long-term memory. That is the reason why they are able to do post-tests well and get high scores. The conclusion above has proven the contribution of drill techniques to improving student competence and English performance.

Suggestion

Based on the conclusions above, it is suggested that English teachers use familiar English-language drill techniques, especially to help students learn, understand, memorize, and remember the form of irregular verbs with their meaning and function to improve their competence in English. English because it's getting higher

\section{BIBLIOGRAPHY}

Abu, Ahmad. 1986. Metode Khusus Pendidikan Agama. Bandung: CV Amrico Anitah, Sri. 2009. Teknologi Pembelajaran. Surakarta : Yuma Pustaka.

Basrowi \& Suwandi. 2008. Prosedur Penelitian Tindakan Kelas. Bogor: Ghalia Indonesia

Nana, Sudjana. 1991. Dasar-Dasar Proses Belajar Mengajar. Bandung: Sinar Baru

Rohman, Arif. 2009. Memahami Pendidikan \& Ilmu Pendidikan. Yogyakarta: LaksBang Mediatama.

Nana, Sudjana. 1991. Dasar-Dasar Proses Belajar Mengajar. Bandung: Sinar Baru

Roestiyah, NK. 1989. Strategi Belajar Mengajar. Jakarta: Bina Aksara

Sardiman. 2007. Interaksi dan Motivasi Belajar Mengajar. Jakarta: Raja Grafindo Persada

Slameto. 1995. Belajar dan Faktor-Faktor Yang Mempengaruhinya. Jakarta :

Winarno, Surakhmad. 1994. Pengantar Interaksi Belajar Mengajar. Bandung 